\title{
Safety assessment of essential oils from Xylopia aethiopica (Dunal) fruit from Nigeria
}

\author{
Raphael Chukwuma Ekeanyanwu*, Nnaemeka Emmanuel Mgbedo, Alvan Tochukwu Njoku
}

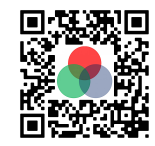

Use your smartphone to scan this QR code and download this article

Department of Biochemistry, Imo State University Owerri, Imo State

Correspondence

Raphael Chukwuma Ekeanyanwu

Department of Biochemistry, Imo State

University Owerri, Imo State

Email: ekeanyanwuraphael@yahoo.com

History

- Received: Mar 28, 2020

- Accepted: Jun 08, 2020

- Published: Jul 31, 2020

DOI : 10.15419/bmrat.v7i7.616

\section{Check for updates}

\section{Copyright}

(c) Biomedpress. This is an openaccess article distributed under the terms of the Creative Commons Attribution 4.0 International license.

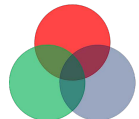

\begin{abstract}
Introduction: The essential oils of Xylopia aethiopica fruits have been reported to possess numerous biochemical effects. However, no toxicological data is available regarding the safety evaluation of the essential oils from the plant spice. The present study was performed to evaluate the safety of essential oils from $X$. aethiopica (XAEO) fruit by acute and sub-acute oral toxicity studies in experimental rodents. Methods: In assessing the safety of XAEO, acute and sub-acute oral toxicity tests were performed following OECD guidelines 425 and 407, respectively, with slight modifications. At the end of each test, hematological and biochemical analysis of the collected blood was performed. Histopathological examination of vital organs of the animals was conducted for gross findings and for comparison to controls. Results: In acute oral toxicity, signs of toxicity were observed in the initial period of the experiment which culminated in the death of the mice before the end of the experiment. The sub-acute test observations indicated that generally, there were no significant differences $(p<0.05)$ up to the high dose level compared to the controls. Conclusion: This study demonstrated the tolerability of XAEO administered daily for 28 days up to $450 \mathrm{mg} / \mathrm{kg}$ dose.

Key words: Xylopia aethiopica, Essential oils, Toxicity, Acute, and Sub-acute, drug tolerance, toxicological study, plant extraction
\end{abstract}

\section{INTRODUCTION}

Several works of literature on essential oils have defined them simply as volatile groups of odorous compounds extracted from diverse herbs and spices. Essential oils are a complex mixture which consists mostly of Monoterpenes and Sesquiterpenes, Alcohols, Esters and Aldehydes, as well as Ketones ${ }^{1}$. Essential oils have found application in medicine as disinfectants, insecticides, repellents, fragrances, and mood stimulants ${ }^{2}$. Recently, it has been shown that essential oils alone or in combination have therapeutic uses in the prevention of cancer, cardiovascular diseases, gastric peptic ulcer, and dental hygiene. Essential oils are also known to exhibit antibacterial, antioxidant, antimicrobial, anti-inflammatory and antiviral properties in animal and cell models ${ }^{3}$. The most noticeable use of essential oil in recent times is in aromatherapy and massage therapy. Many of the essential oils are not safe to consume and can cause serious poisoning even when small concentrations are inhaled and/or ingested ${ }^{1}$.

$X$. aethiopica (African pepper) is an underutilized spice used as food in Africa and most parts of Asia. There are several documented reports on the usefulness of this spice in traditional medicine to relieve toothache, dysentery, diarrhea, dermatitis, headache, cough, stomach ache, dizziness, amenorrhea, bronchitis, neuralgia, flatulence (as a carminative), female sterility, bowel issues (as a purgative), biliousness, and skin infections. Previous studies on the essential oils of $X$. aethiopica fruit have extensively reported on their chemical compositions ${ }^{4-7}$, as well as the antimicrobial, antifungal, antineoplastic and antihypertensive potencies in cells and animal models ${ }^{6,8-10}$.

Despite the reported numerous biochemical effects of the essential oils of $X$. aethiopica fruit, no toxicological data is available regarding the safety evaluation of the essential oils from the plant spice. Given these circumstances, the present study was designed to augment to the research in the literature on essential oils of $X$. aethiopica fruit with the following objectives:

1. To extract the essential oils from the $X$. aethiopica fruit.

2. To carry out a safety assessment of the essential oils from $X$. aethiopica fruit by acute and sub-acute oral toxicity studies in experimental rodents.

\section{MATERIALS - METHODS}




\section{Ethics Approval}

The Animal Experimentation Committee of Imo State University, Department of Biochemistry (Owerri, Imo State, Nigeria) approved the methodology for all animal experiments carried out in this study with protocol number 01/2019. Processes involving experimental animals were carried out per the National Institute of Health Care Guide for the Care and Use of Laboratory Animals (NIH publication \#85 - 23, revised in 1985). This research project was conducted from March 2019 to September 2019. All efforts were made to minimalize the animals' pain and to reduce the number of animals used in the experiments.

\section{Reagents and Instruments}

The reagents used in this experiment were of analytical grade. The instruments used in the present study as listed as follows: Manual Blender (Corona, Landers Colombia), Glass Clevenger apparatus (Deschem Equipment Co. Ltd), LowTemperature Freezer (Haier Thermocool), Ohaus Electronic Balance (Adventurer" Analytical Model AX124, Ohaus GmbH, Europe), Auto-hematology analyzer (icell-820, China), Audicom Auto-analyser (AC-9900, China), Mindray Biochemistry Analyser (BA-88, India), Guillotine (Harvard Apparatus, USA), Glucose Metre Device (Accu-chek, Roche Diagnostics, GmbH, Germany), Spectrophotometers (SpectraMax ${ }^{\circ}$ M Series), optical microscope [Nikon Eclipse E600, USA $(\times 400)]$, and Abbe Refractometer (Model: 2WAJ, Optika, Italy).

\section{Extraction of $X$. aethiopica essential oils}

The authenticated fresh fruits of $X$. aethiopica ${ }^{11}$ were shade dried for 72 hours and pulverized using a manual laboratory blender. The ground fruit $(0.65 \mathrm{~kg})$ from the plant material was maintained with distilled water ( $5 \mathrm{~L}$ ) at $35 \pm 2{ }^{0} \mathrm{C}$ for 7 days and subjected to hydrodistillation using an all-glass Clevenger apparatus for $4 \mathrm{~h}$ according to the method described by Oliveira et al. ${ }^{12}$ with slight modifications. To ensure high quality of the extracted essential oil, extraction was done from one batch of the $X$. aethiopica fruit harvested from the same plant harvested in the same month. The essential oil was separated from hydrolyte by liquid-liquid partitioning, removed with a micropipette, stored in a sterile amber glass vial, and kept in a refrigerator at $4^{0} \mathrm{C}$ without any further treatment until use for analysis. The purity of the essential oil was determined using a Refractometer by comparing the refractive index with available data. The yield of XAEO was calculated and approximated as a percentage (v/w) based on the weight of the dried samples used for extraction.

\section{Experimental Animals}

Forty-eight healthy male Wister albino rats (103 g $203 \mathrm{~g}$ in weight) and 5 Swiss albino mice $(18 \mathrm{~g}-24 \mathrm{~g}$ in weight) were used to carry out the studies. The Veterinary Research Institute of Vom Jos, Nigeria supplied the mice and rats.

\section{Housing and Husbandry}

To allow for free and unhindered access to diet and water, animals were housed individually under standard colony and specific pathogen-free conditions and maintained with a 12-hour light/dark cycle (lights on at 6:00 am) at $25{ }^{0} \mathrm{C}-27{ }^{0} \mathrm{C}$ and relative humidity of $40-60 \%$.

\section{Animal Experiments}

\section{Acute toxicity studies in mice}

For the evaluation of the oral acute toxicity profile of the essential oils in mice, a limit test was carried out according to the fixed-dose procedure (FDP, guideline 425) of the Organization for Economic Co-operation and Development (OECD) guideline $425^{13}$. Briefly, 5 swiss albino mice were randomly selected, marked with a marker for easy identification and kept in separate cages for 7 days to acclimatize to the laboratory conditions. After acclimatization, 1 mouse was first dosed with $2000 \mathrm{mg} / \mathrm{kg}$ of XAEO separately after an overnight fast in a single dose through the oral route $(2 \mathrm{ml}$ of corn oil served as the vehicle for diluting the essential oils). Thereafter, the mice were denied access to food only for $4 \mathrm{~h}$ and were then observed for another $48 \mathrm{~h}$ for mortality. Since there was no mortality, the remaining 4 mice were treated with a similar dose of $2000 \mathrm{mg} / \mathrm{kg}$ of XAEO, respectively. The mice were observed afterwards at approximately $30 \mathrm{~min}, 1 \mathrm{~h}, 2 \mathrm{~h}$, and $4 \mathrm{~h}$ on day 1 and once daily for 14 days for mortality, bodyweight, visual observations (changes in eyes and mucous membranes, skin and fur), and behavioral patterns (alertness and positioning of animals).

\section{Sub-chronic toxicity studies in rats}

The sub-acute (28-day) oral toxicity study in rats was done as stated by the OECD 407 guidelines ${ }^{14}$ for toxicity testing with slight modifications. Following 7 days of acclimatization which allowed for the rats to adapt to their new environment, the rats were randomly divided into 5 groups ( $\mathrm{n}=5$ per group), according to their bodyweight. Rats in group I were left untreated, rats in group II were dosed orally with $2 \mathrm{ml}$ of corn oil (vehicle used for diluting the essential oils), rats in group III to group $\mathrm{V}$ were dosed orally with 
corn oil and different doses of XAEO (150 mg/kg, 300 $\mathrm{mg} / \mathrm{kg}$ and $450 \mathrm{mg} / \mathrm{kg}$ ), with all samples also diluted in $2 \mathrm{ml}$ of corn oil. The essential oils were given orally (gavage) once daily for 28 consecutive days. Throughout treatment, the bodyweight of each rat was monitored on day 0 , and then on the $7^{\text {th }}$ day, $14^{\text {th }}$ day, $21^{\text {st }}$ day and $28^{\text {th }}$ day. The food consumption pattern and individual water intake for all the rats in the groups were also monitored from the $1^{\text {st }}$ to $28^{\text {th }}$ day.

The animals were denied access to food overnight on the $28^{t h}$ day and the $29^{\text {th }}$ day. The fasted rats were anesthetized with chloroform inhalation in a container containing cotton wool soaked with chloroform; then about $10 \mathrm{ml}$ of blood were withdrawn through the retro-orbital sinus ${ }^{15}$. For the analysis of biochemical and hematological parameters, blood samples were prepared according to the method described by Ekeanyanwu and Njoku ${ }^{15}$. Briefly, for the analysis of hematological parameters, about $5 \mathrm{ml}$ of the collected blood sample was immediately transferred into another sample bottle containing EDTA and shaken mildly to mix the blood and prevent clotting. For the analysis of biochemical parameters, about $5 \mathrm{ml}$ of blood from each rat was transferred to a test tube and kept at ambient temperature for 30 min to clot. Afterwards, the test tubes containing the clotted blood sample were centrifuged at 3,000 $\mathrm{rpm} / \mathrm{min}$ for $10 \mathrm{~min}$ to enable complete separation of serum from the clotted blood. The clear serum supernatants were then carefully drawn out with a syringe and stored in clean sample containers for biochemical analysis.

\section{Biochemical analysis}

The values for lipid profile (Cholesterol, Triglycerides, HDL and LDL), total serum protein (Serum Protein, Albumin, and Globulin), renal profile (Urea, Creatinine, $\mathrm{Na}^{+}, \mathrm{Cl}^{-}, \mathrm{K}^{+}, \mathrm{BCO}_{3}{ }^{2-}$ ), and liver profile (ALT: Alanine aminotransaminase, AST: Aspartate transaminase, ALP: Alkaline phosphatase, TB: Total bilirubin, CB: Conjugated bilirubin) in rats were determined using standard laboratory procedures. All the biochemical parameters were analyzed using standard laboratory kits and equipment for the different parameters, according to their various manufacturers' guidelines and at room temperature $\left(27.0 \pm 0.5^{0} \mathrm{C}\right)$. However, blood glucose level was determined in all groups on the first day of the animal experiment and before blood collection using a glucose meter device.

\section{Hematological analysis}

The values for erythrocyte sedimentation rate (ESR), White Blood Cell (WBC) Count, Red Blood Cell
(RBC) Count, Hemoglobin (Hb) Concentration, Mean Corpuscular Hemoglobin (MCH), Mean Corpuscular Volume (MCV), Mean Corpuscular Hemoglobin Concentration (MCHC), Platelet Count, and the number of Lymphocytes, Neutrophils, Monocytes and Eosinophils, were all determined at room temperature $\left(27 \pm 0.5^{\circ} \mathrm{C}\right)$. WBC Count, RBC Count, Hemoglobin Concentration, Mean Corpuscular Hemoglobin, Mean Corpuscular Volume, Mean Corpuscular Hemoglobin Concentration, Platelet Count, and the number of Lymphocytes, Neutrophils, Monocytes and Eosinophils, were determined using the Automatic Hematology (icell-820) analyzer. Erythrocyte sedimentation rate was determined by the method of Westergren as described by Mbaka et $a l^{16}$. Packed cell volume was determined spectrophotometrically using the cyanomethemoglobin method as described by Mbaka and Adeyemi ${ }^{17}$.

\section{Organ weight}

The liver, kidney, heart, brain and spleen of rats in the various groups were removed surgically on day 29 immediately after blood collection. Following removal, the organs were shaved of irrelevant tissues, and placed on a Petri dish containing $10 \%$ normal saline. Organs were dried with cotton wool and immediately weighed (paired organs were weighed together) to one decimal place and calculated for organ weight ratio ${ }^{15}$.

Organ weight ratio $=\frac{\text { Organ weight }(g)}{\text { Bodyweight }(g)} \times 100$

\section{Histopathology}

The procedure described by Ekeanyanwu and Njoku $^{15}$ was used for post-mortem examination of the liver, kidney, heart, brain and spleen of the rats in the various groups. A veterinary pathologist, without any knowledge of the treatments and groups, performed the histopathologic examination on the de-waxed, hydrated and hematoxylin-eosin stained ultrathin sections of the tissue samples with an optical microscope.

\section{Statistical analysis}

Changes in all biochemical and hematological factors, body and organ weight, and water and feed intake for the rats, were determined using a one-way analysis of variance (ANOVA) followed by Turkey multiple comparisons. A p-value of less than 0.05 was considered as statistically significant. All data obtained were expressed as Mean \pm Standard Error of the Mean (Mean \pm SEM). 


\section{RESULTS}

\section{Body weight}

Figure 1 shows the effect of administration of different doses of the essential oils of $X$. aethiopica fruit on the bodyweight of rats. There was a gradual and sustained increase in the bodyweight of rats in all the experimental groups all through the duration of the animal experiments. Analysis of the result shows that the gain (in percentages) of bodyweight after 28 days were $17.9 \%$ in group I, $23 \%$ in group II, $6.84 \%$ in group III, $3.40 \%$ in group IV, and $11.32 \%$ in group V, respectively.

\section{Hematological parameters}

The results of the hematological parameters in rats administered with different doses of the essential oils of $X$. aethiopica fruit are depicted in Figure 2. Analysis of the results shows that there were no significant differences $(p<0.05)$ in the various hematological parameters analyzed in the test groups as compared to the control.

\section{Biochemical parameters}

The results of the biochemical tests such as liver function profile, kidney function profile, serum lipid profile, and blood sugar levels are presented in Figures 3, 4,5 and 6 . The results of the liver function test showed no significant changes $(\mathrm{p}<0.05)$ between the experimental groups and the controls for all the biochemical parameters analyzed. Analysis of the results of the kidney function test revealed significant changes $(\mathrm{p}<$ 0.05 ) between the experimental groups and the controls, except for BUN and serum chloride which were found to have significantly $(\mathrm{p}<0.05)$ increased in the test groups compared to the control. The results of the serum lipid profile test did not show any significant changes ( $p>0.05$ ) between the experimental groups and the controls with respect to lipid profile parameter. However, a significant decrease $(p<0.05)$ was observed in the blood sugar level in the control and experimental groups after 28 days of administration of XAEO, when compared to day 0.

\section{Organ weight/Organ weight ratio}

The result of the organ weight/organ weight ratio is presented in Table 1. A significant decrease ( $p<$ 0.05 ) in the weight of organs such as liver, kidney and spleen was noticed in the group administered with $450 \mathrm{mg} / \mathrm{kg}$ b.wt of XAEO.

\section{Histopathological parameters}

The following were observed from histological examinations and were set as the parameters: (a) No pathological changes in the histological sections of the heart; (b) No pathological changes in the liver of rats in all the treated groups except for the group administered with $450 \mathrm{mg} / \mathrm{kg}$ b.wt of EOXA (slightly enlarged hepatocytes were observed); (c) No pathological changes in the histological sections of the brain; (d) No pathological changes in the kidney of rats in all treated groups except for the group administered with $450 \mathrm{mg} / \mathrm{kg}$ b.wt of EOXA (slightly enlarged hepatocytes were observed); and (e) No pathological changes in the histological sections of the spleen.

In the heart, there were unremarkable myocyte nuclei, muscle fibres, and myocardium; no pathological changes were observed. In the liver, stromal proliferation with degenerative changes was observed with slightly enlarged hepatocytes, distorted sinusoids and lamina, and few cystically dilated spaces in Group I and Group II. There was mild stromal proliferation and unremarkable central vein, sinusoids, lamina and hepatocytes with no pathological changes in Group III and Group IV. Furthermore, the proliferation of tissue stromal with an enlarged central vein, sinusoids and lamina appearing unremarkable in some areas and distorted in other areas, as well as slightly enlarged hepatocytes, were seen in Group V. In the Brain, normal Purkinje cells, stellate cells, dendrites of Purkinje cells, and pyramidal cells along with granule cells were observed; no pathological changes were seen. In the Kidney, there were unremarkable stromal arrangements, glomeruli, Bowman's capsule, tuft, tubules and other stromal elements with no pathological changes seen in A, B, C and C, whereas E showed unremarkable tubules and glomeruli closely adherent to the Bowman's capsule and dense stroma with mild proliferation. In the spleen, splenic nodules with unremarkable germinal centers were observed. Surrounding the splenic nodules and intermeshed with trabeculae was a diffuse mass of cells (lymphocytes) which collectively formed the splenic pulp.

\section{DISCUSSION}

The major findings from this research study can be summarised as follows: (a) $\mathrm{LD}_{50}$ of the essential oils of X. aethiopica was below $2000 \mathrm{mg} / \mathrm{kg}$ bodyweight; (b) the results of the subacute toxicity study showed no sign of toxicity at our tested doses, as shown in the biochemical and haematological parameters assayed; and (c) histological examination of target organs such as brain, heart, kidney, liver and spleen revealed no remarkable changes. 


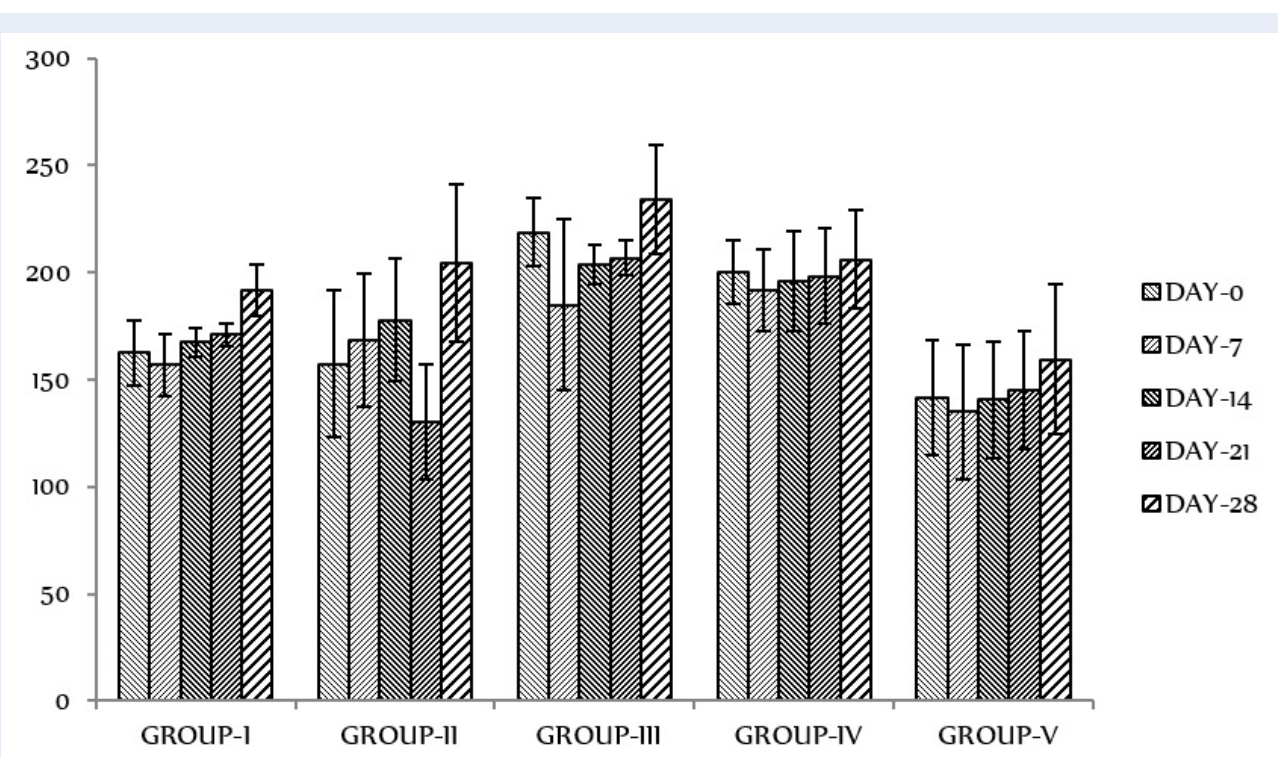

Figure 1: Effect of administration of different doses of the essential oils of $X$. aethiopica fruit on bodyweight (grams) of rats. Data are shown as mean $\pm \operatorname{SEM}$ ( $n=5$ rats per group). There was a gradual and sustained increase in the bodyweight of rats in all the experimental groups all through the duration of the animal experiments.

The essential oils extracted from the dry fruit of $X$. aethiopica based on hydrodistillation yielded $1.98 \%$ (v/w). The hydro distilled essential oil was found to be $100 \%$ pure with a refractive index of $1.461-1.489$. The value is comparable to that previously reported by Olonisakin et al. ${ }^{18}$ from dry fruits of X. aethiopica obtained from Nigeria (which was $1.2 \%(\mathrm{v} / \mathrm{w})$ ). The value is, however, lower than that discussed elsewhere in Africa where Tegang et al. ${ }^{10}$ reported extraction yield of $4.2 \%(\mathrm{v} / \mathrm{w})$ for dry fruits of $X$. aethiopica Cameroun and Bakan-Vla et al. ${ }^{6}$ also reported similar values of $3.57 \%(\mathrm{v} / \mathrm{w})$ and $4.68 \%(\mathrm{v} / \mathrm{w})$ from dry fruits of $X$. aethiopica, respectively. The dissimilarity in the extraction yield could be attributed to plant age, provenance, weather, soil conditions (in the cultivation of the spice), harvest time, and extraction technique, as well as the drying technique, employed in the processing of the essential oils ${ }^{19,20}$.

Several previous studies on the chemical profile of the essential oils of $X$. aethiopica reported in Nigeria and within the West Africa sub-region show that the oils contain more than 70 different chemical compounds which can be divided into four chemical classes: monoterpene hydrocarbons, oxygenated monoterpenes, oxygenated sesquiterpenes, and sesquiterpene hydrocarbons ${ }^{6,7,10,21-24}$. Zárybaický et al. ${ }^{25}$ communicated in a review that several of these monoterpenes and sesquiterpenes have demonstrated hepatotoxicity which were linked to reactive metabolite formation and increased oxidative stress. The major chemical compounds identified in the essential oils of $X$. aethiopica included $\alpha$-pinene, $\beta$-pinene, $\alpha$ phellandrene, and $\beta$-phellandrene (Figure 1). Preliminary toxicological reports on these chemical compounds showed that repeated oral administration at lower doses caused hepatotoxicity (liver enzyme induction) while lethal doses produced local irritation, central nervous system depression, and respiratory failure in rodents ${ }^{25}$.

Typically, determining the toxic characteristics of products from medicinal plants is a preliminary phase in screening natural products for pharmacological activity. The determination of $\mathrm{LD}_{50}$ is normally an initial step during such an assessment. The acute toxicity analysis may provide initial information on an agent's mode of toxicity, serve as a basis for classification and labelling, and aid in determining the dose of new compounds in animal studies. For addition, if a high dose (e.g. $5000 \mathrm{mg} / \mathrm{kg} \mathrm{b.wt)}$ is found to be survivable, there will be no further toxicity testing required $^{26}$.

The findings of the acute toxicity analysis provided valuable information about the effects of brief exposure of the test animals to high doses of XAEO. During the administration of XAEO to Swiss albino mice at a maximum test dose of $2000 \mathrm{mg} / \mathrm{kg}$ b.wt, and throughout the 14-day duration of perception, notable changes were observed in mice, ranging from 


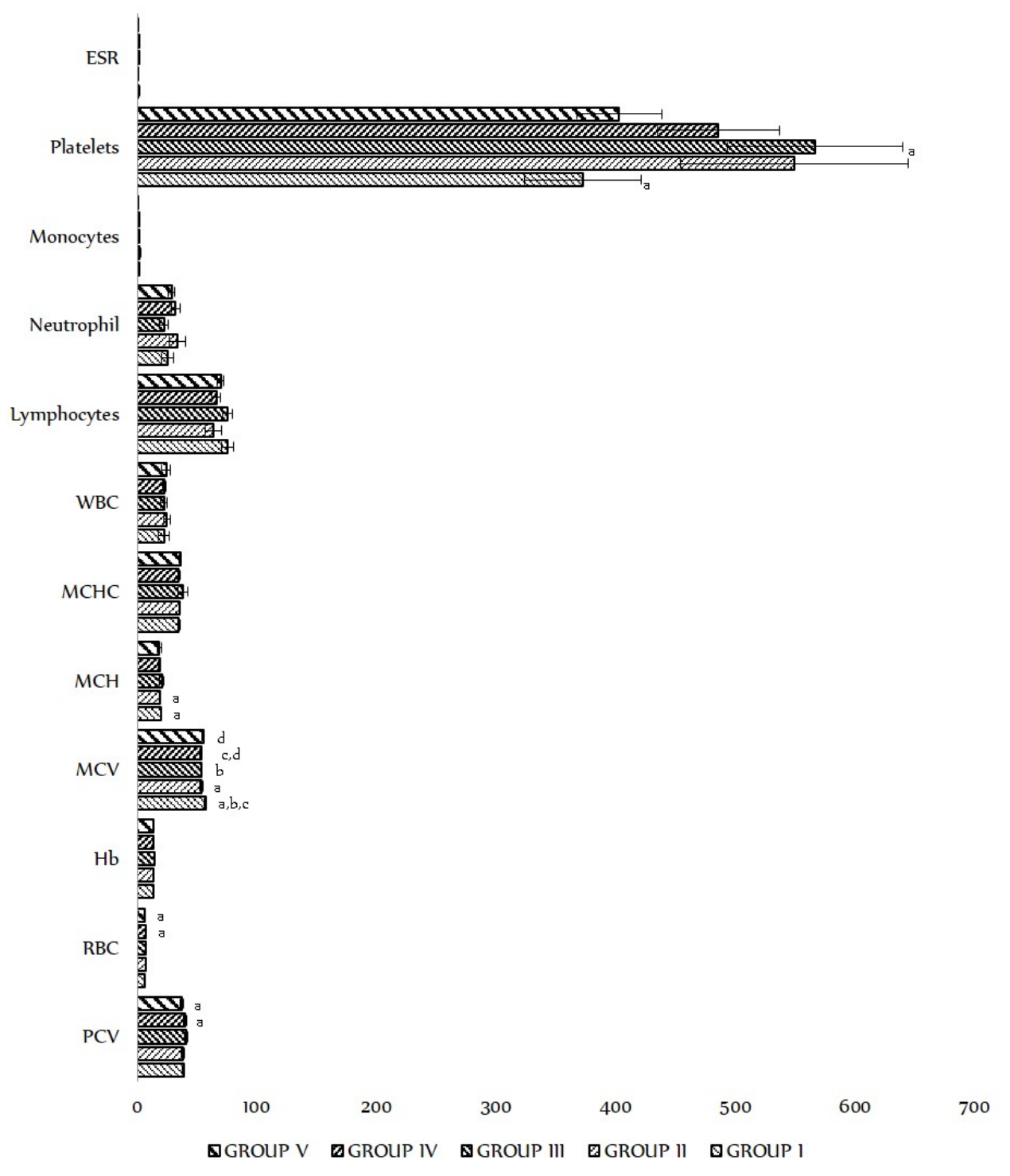

Figure 2: Hematological indices in rats administered with different doses of the essential oils of $X$. aethiopica fruit. Data are shown as mean \pm SEM ( $n=5$ rats per group). Values on the same row followed by superscript letters differ significantly $\left({ }^{a} \mathrm{p}<0.05\right)$. Eosinophils were not detected in the blood samples from the rats in each group. Note: PCV (\%), RBC ( $\left.\times 10^{12} / \mathrm{L}\right), \mathrm{Hb}(\mathrm{g} / \mathrm{dl}), \mathrm{MCV}(\mathrm{fl}), \mathrm{MCH}(\mathrm{pg}), \mathrm{MCHC}(\mathrm{g} / \mathrm{dl}), \mathrm{WBC}\left(\times 10^{9} / \mathrm{L}\right)$, Lymphocytes (\%), Neutrophil (\%), Monocytes (\%), Eosinophils (\%), and Platelets ( $\left.\times 10^{9} / \mathrm{L}\right)$, ESR (mm/hr).

decreased alertness, slow breathing, loss of appetite, ruffled hair, loss of hide and fur, and blood traces in fecal matter.

As well, treatment-related changes were seen with decreased preparation and uncomfortable positioning of the body, as well as decreased weight. Besides, $50 \%$ of deaths were reported on the $5^{\text {th }}$ day and $100 \%$ of deaths were recorded on the $7^{\text {th }}$ day during XAEO administration. In this manner, XAEO cannot be said to be safe at a dose level of $2000 \mathrm{mg} / \mathrm{kg}$ bodyweight and hence, the $\mathrm{LD}_{50}$ value for oral toxicity can be said to be below $2000 \mathrm{mg} / \mathrm{kg}$.

Sub-acute studies include information on treatment regimens, target organ toxicity, and classification of reported adverse effects, all of which may impact the experimental animals' average life span. Analysis of data on the effects of the sub-acute oral toxicity study in Wistar albino rats showed no signs of toxicity such as ataxia, decreased motor activity, excessive grooming, muscular stiffness and ruffled furs, as recorded 


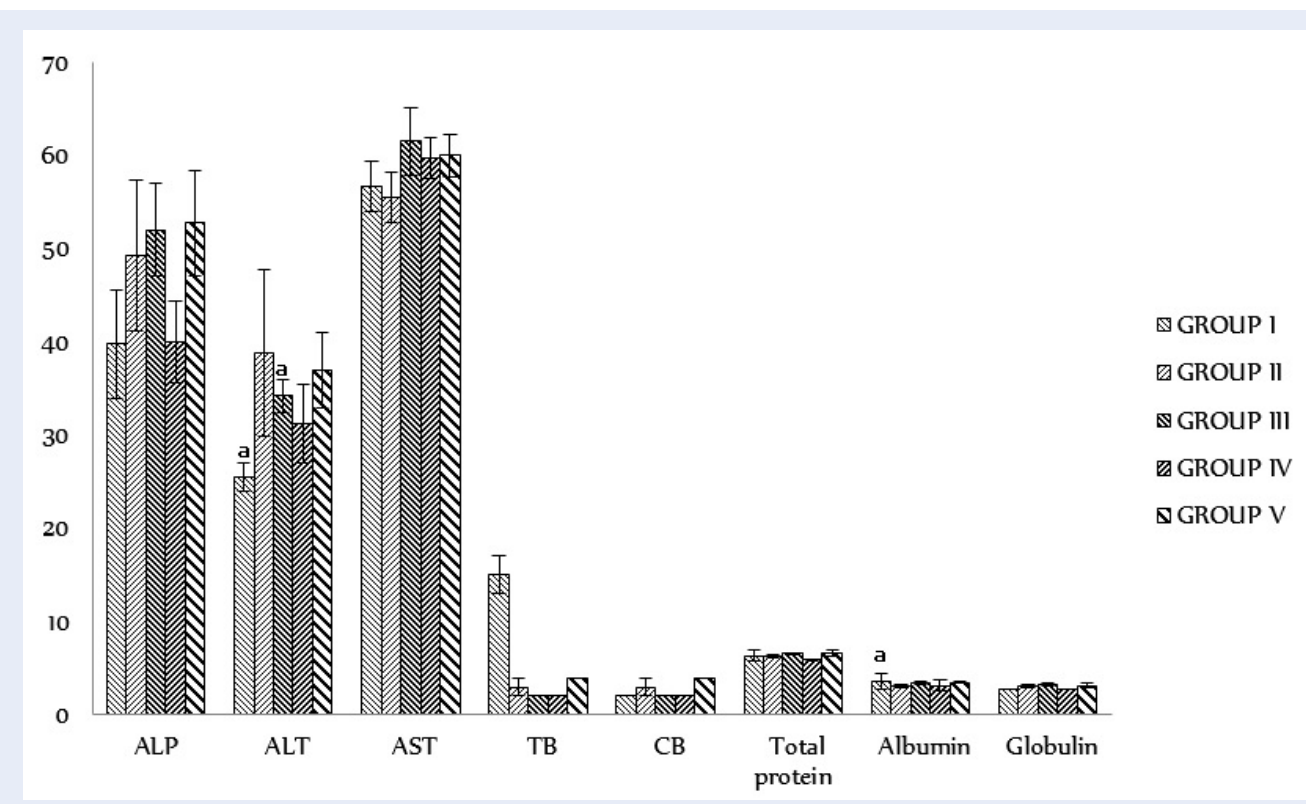

Figure 3: Liver function test parameters in rats were administered at different doses of the essential oils of $X$. aethiopicafruit. Values are represented as mean $\pm \operatorname{SEM}$ ( $n=5$ rats per group). Values on the same row followed by superscript letters differ significantly $\left({ }^{a} \mathrm{p}<0.05\right)$. Note: ALP (IU/L), ALT (IU/L), AST (IU/L), TB $\times\left(10^{-2}\right) \mathrm{mg} / \mathrm{dl}, \mathrm{CB}$ $\times\left(10^{-2}\right) \mathrm{mg} / \mathrm{dl}$, Total protein ( $\left./ \mathrm{dl}\right)$, Albumin (g/dl), and Globulin $(\mathrm{g} / \mathrm{dl})$.

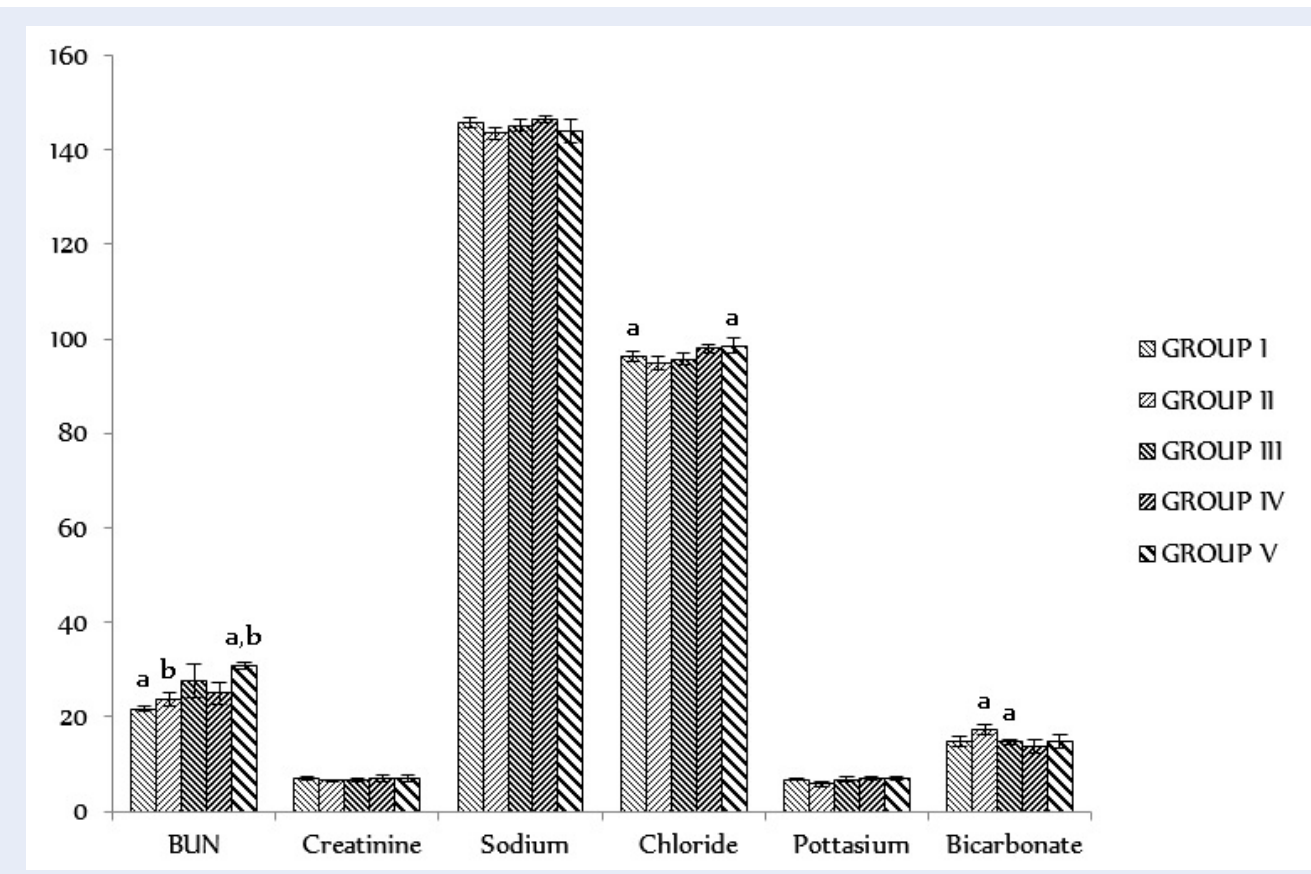

Figure 4: Kidney function and serum electrolyte parameters in rats administered with different doses of the essential oils of $\boldsymbol{X}$. aethiopica fruit. Values are represented as mean $\pm \operatorname{SEM}(\mathrm{n}=5$ rats per group). Values on the same row followed by superscript letters differ significantly $\left({ }^{a, b} \mathrm{p}<0.05\right)$. Note: BUN $(\mathrm{mg} / \mathrm{dl})$, Creatinine $\left(\mathrm{mg} / \mathrm{dl} \times 10^{-1}\right)$, Sodium $(\mathrm{Mmol} / \mathrm{l})$, Chloride $(\mathrm{Mmol} / \mathrm{l})$, Potassium $(\mathrm{Mmol} / \mathrm{l})$, and Bicarbonate $(\mathrm{Mmol} / \mathrm{l})$. 


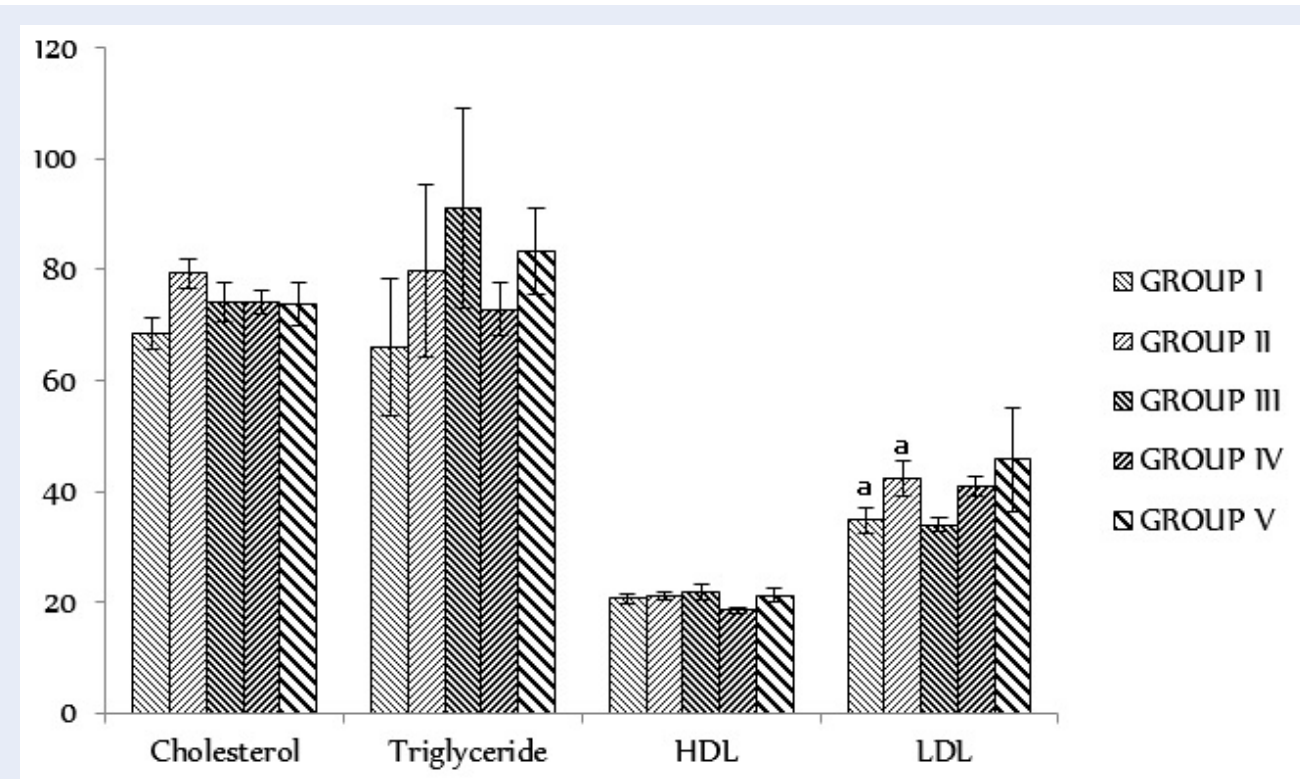

Figure 5: Serum lipid profile test in rats administered with different doses of the essential oils of $X$. aethiopica fruit. Values are represented as mean \pm SEM ( $n=5$ ratsper group). Values on the same row followed by superscript letters differ significantly $\left({ }^{a} \mathrm{p}<0.05\right)$. Note: Cholesterol $(\mathrm{mg} / \mathrm{dl})$, Triglyceride $(\mathrm{mg} / \mathrm{dl}), \mathrm{HDL}(\mathrm{mg} / \mathrm{dl})$, and LDL (mg/dl).

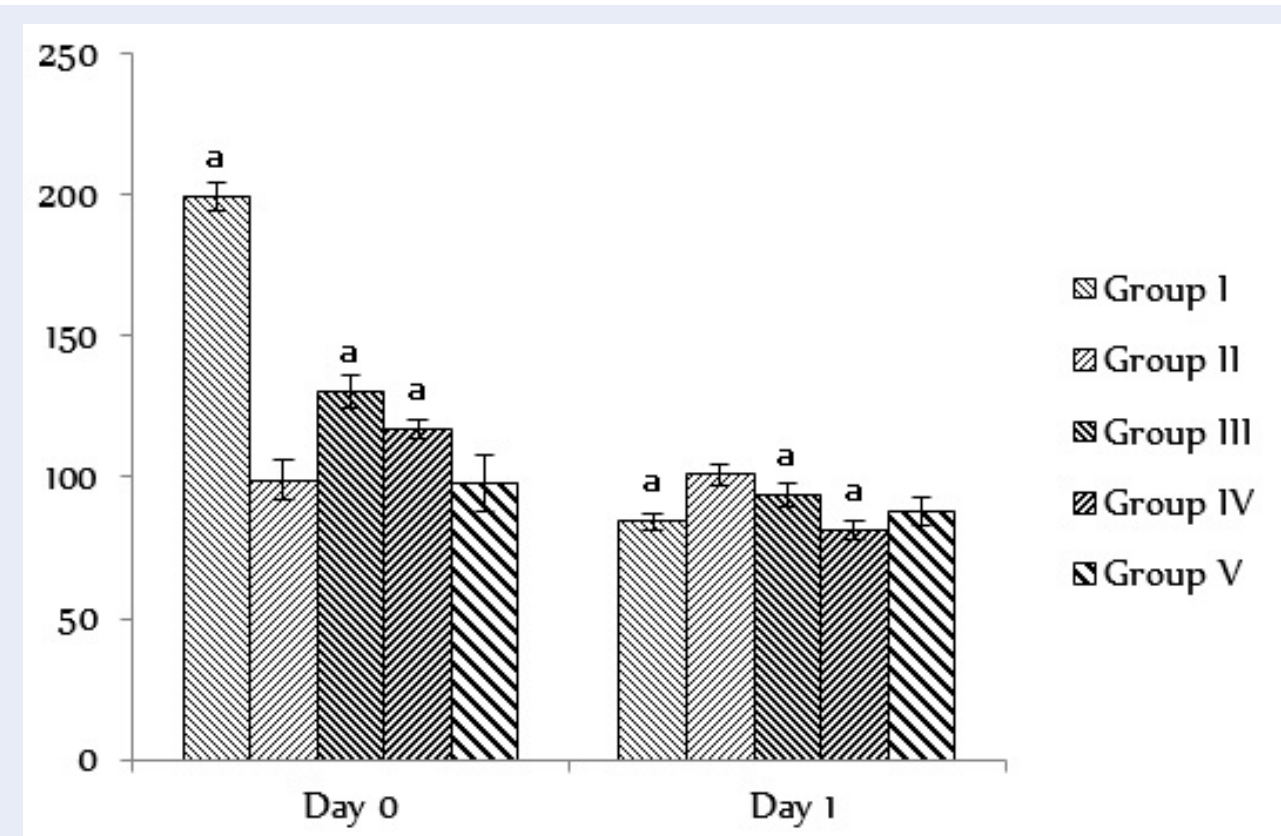

Figure 6: Blood sugar level (Mg/dl) at Day 0 and Day 1 in rats administered with different doses of the essential oils of $\boldsymbol{X}$. aethiopica fruit. Values are represented as mean $\pm \operatorname{SEM}(n=5$ rats per group). Values on the same row followed by superscript letters differ significantly $\left({ }^{a} \mathrm{p}<0.05\right)$. 


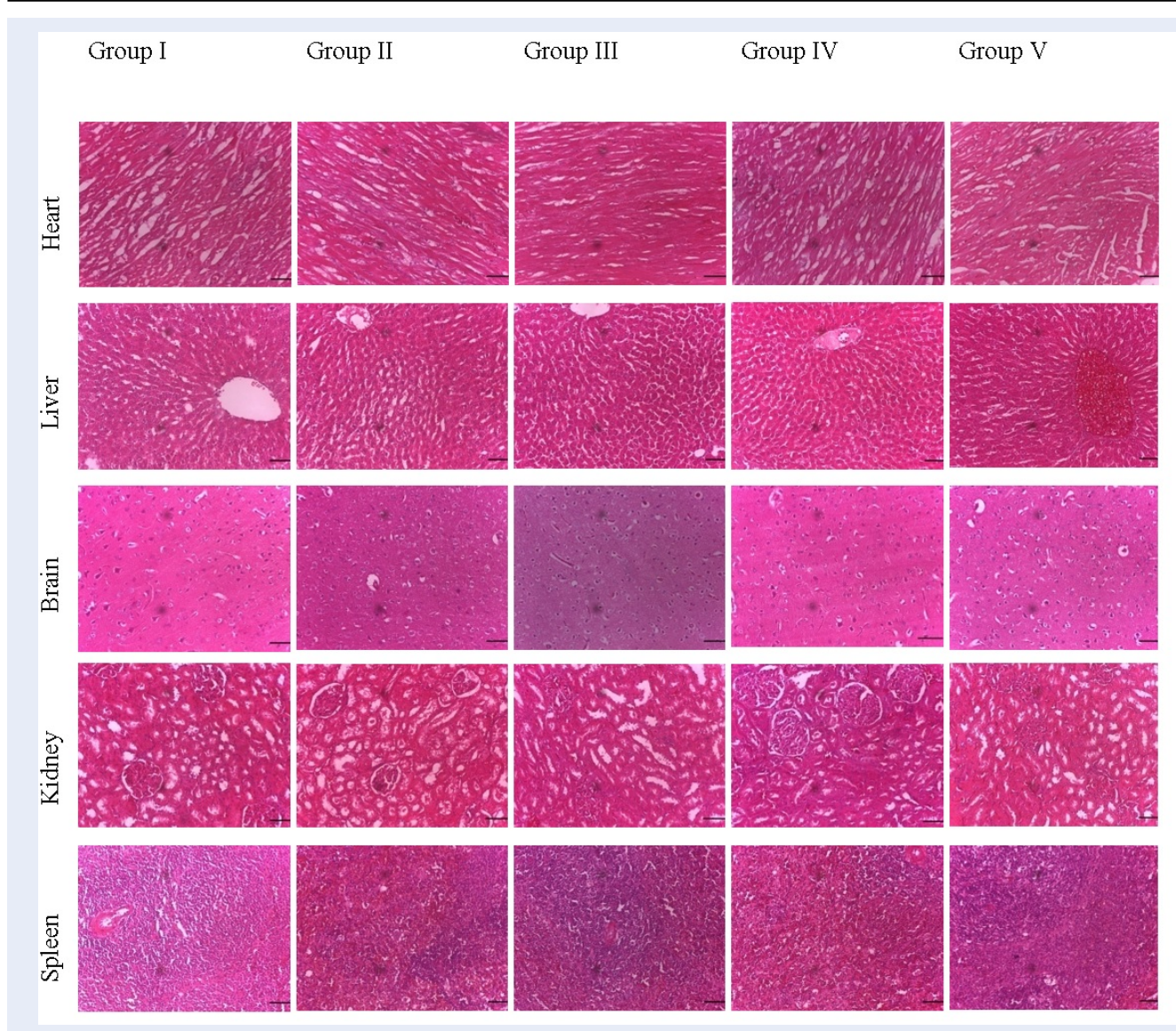

Figure 7: Histological sections of the heart, liver, brain, kidney and spleen in rats administered with different doses of the essential oils of $X$. aethiopica fruit. $\mathrm{H}$ and $\mathrm{E} \times 240$, Scale Bar $=20 \mu \mathrm{m}$. No abnormalities were observed on gross or histopathological evaluations of the organs examined. Generally, no pathological changes were observed in the brain, heart, kidney, liver or spleen of the animals administered with the different doses of the XAEO in the subacute oral toxicity studies.

during the 28 consecutive days of treatment via oral route with the essential oils at the doses of $150 \mathrm{mg} / \mathrm{kg}$, $300 \mathrm{mg} / \mathrm{kg}$ and $450 \mathrm{mg} / \mathrm{kg}$ bodyweight, respectively.

The percentage of bodyweight gain of the Wistar rats was not affected by the essential oil treatment compared to control (Table 1). During the treatment period, however, minor differences in food and water intake were observed compared to the control group. If taken together, toxic symptoms, and food and water consumption can suggest malaise or hidden toxicity long before signs are observable. For instance, if an animal does not feel well, it will not eat enough food and/ or drink the normal amount of water. Therefore, bodyweight, fat, and water intake are general health predictors. Moreover, these criteria are critical for deterring a drug's safety during the sub-acute toxicity study. During the treatment period, however, minor differences in food and water intake were observed in treated rats compared to the control group. Therefore, these criteria are critical for determining the safety of the extract during the subacute toxicity study ${ }^{27}$.

Changes in bodyweight are a sensitive indicator of the animal's general health status ${ }^{28}$. There was a gradual and sustained increase in the bodyweight of rats in all the experimental groups throughout the duration of the animal experiments (Figure 1). It can be stated that XAEO did not interfere with the normal metabolism of animals at the tested doses. The increment in food and water intake is considered as being responsible for augmentation in bodyweight gain.

The determination of hematological parameters is used to examine the association between the essential oil and the various functions of blood ${ }^{29}$. Porwal et al. ${ }^{29}$ have described the hemopoietic system as one of the most important targets of toxic compounds and a relevant indicator of both human and animal physiological and pathological status. Analysis of the results shows that there were no significant differences 
Table 1: Organ weight/Organ weight ratio in rats administered different doses of the essential oil of Xylopia aethiopica fruit

\begin{tabular}{lcllll}
\hline Parameters & Group I & Group II & Group III & Group IV & Group V \\
Heart $(\mathrm{g})$ & $0.62 \pm 0.05$ & $0.75 \pm 0.09$ & $0.77 \pm 0.04$ & $0.86 \pm 0.10$ & $0.58 \pm 0.09$ \\
& {$[0.32 \pm 0.42]$} & {$[0.37 \pm 0.24]$} & {$[0.33 \pm 0.16]$} & {$[0.42 \pm 0.06]$} & {$[0.36 \pm 0.26]$} \\
Liver (g) & $7.48 \pm 0.21^{a}$ & $6.82 \pm 1.73$ & $8.10 \pm 0.37$ & $7.80 \pm 0.24$ & $6.02 \pm 0.64^{a}$ \\
& {$[3.90 \pm 1.74]$} & {$[3.33 \pm 4.69]$} & {$[3.46 \pm 1.45]$} & {$[3.78 \pm 1.05]$} & {$[3.78 \pm 1.83]$} \\
Kidney (g) & $1.34 \pm 0.02^{a}$ & $1.22 \pm 0.09^{b}$ & $1.47 \pm 0.08$ & $1.48 \pm 0.05$ & $0.98 \pm 0.10^{a, b}$ \\
& {$[0.69 \pm 0.16]$} & {$[0.59 \pm 0.24]$} & {$[0.62 \pm 0.02]$} & {$[0.71 \pm 0.21]$} & {$[0.61 \pm 0.28]$} \\
Spleen (g) & $0.86 \pm 0.21^{a}$ & $0.62 \pm 0.06$ & $0.62 \pm 0.16$ & $0.76 \pm 0.04$ & $0.58 \pm 0.15^{a}$ \\
& {$[0.44 \pm 0.17]$} & {$[0.30 \pm 0.16]$} & {$[0.26 \pm 0.45]$} & {$[0.36 \pm 0.17]$} & {$[0.36 \pm 0.43]$} \\
\hline
\end{tabular}

Values are represented as mean \pm SEM. $\mathrm{N}=5$. Values on the same row followed by superscript letters differ significantly $\left({ }^{a, b} \mathrm{p}<0.05\right)$.

$(\mathrm{p}<0.05)$ in the various hematological parameters analyzed in the test groups compared to the control (Figure 2). Importantly, XAEO treatment induced no significant change $(\mathrm{p}<0.05)$ on the $\mathrm{RBC}$ indices which suggest that the XAEO does not affect erythropoiesis, morphology, or osmotic fragility of RBCs ${ }^{30}$. WBCs are the first line of cellular action that responds to infectious agents, tissue injury, or any inflammation. Furthermore, no significant changes $(\mathrm{p}<0.05)$ were observed in neutrophils, lymphocytes, or monocytes from XAEO treatment, suggesting that the essential oils might not have exerted a challenge on the immune system of the rodents.

Serum biochemistry evaluation was conducted to evaluate possible changes in renal and hepatic functions affected by the essential oils. The results of the serum biochemistry assay are represented in Figures 3, 4, 5 and 6 . The lack of significant alterations in the levels of ALT, AST, ALP, conjugated and total bilirubin, total protein, albumin, globulin and creatinine, as well as some serum electrolytes $\left(\mathrm{Na}^{+}, \mathrm{Cl}^{-}\right.$, $\mathrm{K}^{+}, \mathrm{BCO}^{3-}$ ), which are good indicators of osmotic regulation by blood, kidney and cardiac function, and digestion and intermediary metabolism ${ }^{27,31}$, suggest that sub-chronic administration of the essential oils neither altered hepatocytes and kidneys in rats nor the normal metabolism of the animals. However, a significant increase $(\mathrm{p}<0.05)$ was noticed in the BUN and serum chloride levels only in the test group administered with $450 \mathrm{mg} / \mathrm{kg}$ b.wt of the XAEO, suggesting that at increased doses, the XAEO may possess toxic effects at doses above $450 \mathrm{mg} / \mathrm{kg}$ b.wt. The results of the serum lipid profile tests (Cholesterol, Triglyceride, HDL and LDL), as well as results of blood glucose (at day 0 and day 28), are shown in Figures 5 and 6, respectively. The results show no significant changes ( $\mathrm{p}$ $<0.05)$ in the lipid profile test parameters. These observations were further confirmed by the histological assessment of the organs shown in Figure 7.
In toxicity studies, the protocol for weighing relative organs includes their sensitivity to product toxicity, which correlates well with the histopathological changes ${ }^{28}$. A significant decrease $(p<0.05)$ in the weight of organs, such as liver, kidney and spleen, was noticed in the group administered with $450 \mathrm{mg} / \mathrm{kg}$ b.wt of XAEO, indicating that at a dose of approximately $450 \mathrm{mg} / \mathrm{kg}$ b.wt or more, the liver, kidney and spleen may be adversely affected. The results are presented in Table 1.

In the safety assessment of the test animals, the assessment of histopathological changes in organs was considered as a basic test ${ }^{32}$. No abnormalities were observed on gross or histopathological evaluations of the organs examined. Generally, no pathological changes were observed in the brain, heart, kidney, liver or spleen of the animals administered with the different doses of the XAEO in the subacute oral toxicity studies. However, slight histopathological changes were observed in the liver and kidney of rats administered with $450 \mathrm{mg} / \mathrm{kg}$ b.wt of XAEO, where slightly enlarged hepatocytes and dense stroma with mild proliferation were observed in the liver and kidney, respectively.

\section{CONCLUSION}

With regards to the results of our study herein, it can be inferred that XAEO is not safe at a dose level of $2000 \mathrm{mg} / \mathrm{kg}$ b.wt, based on the outcome of the acute toxicity study. However, it was not toxic at least in all the doses tested in this research study, and there was no development of any obvious symptoms in the subacute oral toxicity studies. The histology examination revealed no significant changes in internal organs such as brain, heart, kidney, liver and spleen in both control and test animals. As well, data from acute and subacute toxicity studies on this plant were obtained to increase people's confidence in their safety 
for use in pharmaceutical development. The experiments also need more experimental activities such as sub-chronic toxicity and the effects of the essential oils on pregnant mouse fetuses. Also, investigation into the pregnant mice's ability to reproduce should complete the spice safety profile.

\section{SIGNIFICANT STATEMENT}

This study shows that the essential oils of $X$. aethiopica are not safe at least at a dose level of $2000 \mathrm{mg} / \mathrm{kg}$ b.wt, considering the results of the acute toxicity study even though there were no evident symptoms in the subacute oral toxicity studies at least below $450 \mathrm{mg} / \mathrm{kg}$ b.wt. The histology examination revealed no remarkable changes in the internal organs such as the brain, heart, kidney, liver and spleen of the rats in both control and treated groups. This study provides valuable information on the toxicity profile of the essential oils of the $X$. aethiopica fruit. The results will be valuable for natural medicine users and pharmaceutical industries who wish to take advantage of the curative effects derivable from the fruit and research scientists who are interested in further exploring the potential benefits of the essential oils.

The study was limited to only male Wistar albino rats. However, studies are also needed to determine the effects of $X$. aethiopica fruit extract on the fetus in a pregnant animal. The reproductive capacity of the animals on the genetic system and the ability of this spice to produce tumors (tumorigenecity and carcinogenicity tests), in addition to effects on drug metabolizing enzymes (especially cytochrome P450s) and toxicokinetic profiling, are future tests that need to be conducted to complete the toxicity profile.

\section{ABBREVIATIONS}

ALP: Alkaline phosphatase

ALT: Alanine aminotransaminase

CB: Conjugated Bilirubin

ESR: Erythrocyte Sedimentation Rate

Hb: Haemoglobin

HDL: High Density Lipoprotein

LDL: Low Density Lipoprotein

MCH: Mean Corpuscular Haemoglobin

MCHC: Mean Corpuscular Haemoglobin Concentration

MCV: Mean Corpuscular Volume

NIH: National Institute of Health

OECD: Organization for Economic Cooperation and

Development

RBC: Red Blood Cell

TB: Total Bilirubin

WBC: White Blood Cell

XAEO: Xylopia aethiopica essential oil

\section{ACKNOWLEDGMENTS}

The authors wish to appreciate the management of Imo State University Owerri, for providing institutional and infrastructural support.

\section{AUTHOR'S CONTRIBUTIONS}

Ekeanyanwu, R. C: Conceptualization, Methodology, Validation, Investigation, Writing - Review \& Editing, Supervision. Mgbedo, N.E: Writing - Original Draft, Project administration, Funding acquisition, Visualization. Njoku, A.T: Project administration, Funding acquisition, Resources. All authors read and approved the final manuscript.

\section{FUNDING}

Not applicable.

\section{AVAILABILITY OF DATA AND MATERIALS}

Data and materials used and/or analysed during the current study are available from the corresponding author on reasionable request.

\section{ETHICS APPROVAL AND CONSENT TO PARTICIPATE}

Not applicable.

\section{CONSENT FOR PUBLICATION}

Not applicable.

\section{COMPETING INTERESTS}

The authors declare that they have no competing interests.

\section{REFERENCES}

1. Vigan M. Essential oils; renewal of interest and toxicity. EJD. 2010;20(6):685 -692. Available from: 10.1684/ejd.2010.1066.

2. Tanu B, Harpreet K. Benefits of essential oils. J Chem Pharm Res. 2016;8(6):143-149. Available from: http://www.jocpr. com/articles/benefits- of-essential-oil.pdf.

3. Sharifi-Rad J, Sureda A, et al. Biological activities of essential oils: from plant chemo-ecology to traditional healing systems. Molecules. 2017;22:70. PMID: 28045446. Available from: https: //doi.org/10.3390/molecules22010070.

4. Onyenekwe PC, Ogbadu G, Deslaurier H, Gagnon M, Collin GJ. Volatile constituents of the essential oil of Monodora tenuifolia (Gaetrn) dunal. J Sci, Food Agric. 1993;61:379. Available from: https://doi.org/10.1002/jsfa.2740610317.

5. Noudjou F, Kouninki $\mathrm{H}$, et al. Composition of Xylopia aethiopica (Dunal) A. rich essential oils from Cameroun and identification of a minor diterpene; ent-13-epi manoyl oxide. Biotechnology Agron Soc Environ. 2007;11(3):193 -199. Available from: https://popups.uliege.be:443/1780-4507/index.php? $\mathrm{id}=830$. 
6. Bakarnga-Vla I, Hzounda JB, et al. Composition and cytotoxic activity of essential oils from Xylopia aethiopica (Dunal) A. Rich, Xylopia parviflora (A. Rich) Benth.) and Monodora myristica (Gaertn) growing in Chad and Cameroon. BMC Complement, Altern, Med. 2014;4(14):125. PMID: 24708588. Available from: https://doi.org/10.1186/1472-6882-14-125.

7. Konan N, Kouare BA, Mamyrbekova-Bekro JA, Nemlin J, YvesAlain BC. Chemical composition and antioxidant activities of essential oils of Xylopia aethiopica (Dunal) A. Rich. EJSR. 2009;37(2):311-318. Available from: doi.org/10.1021/ jf040150j.

8. Asekun OT, Adeniyi BA. Antimicrobial and cytotoxic activities of the fruit essential oil of Xylopia aethiopica from Nigeria. Fitoterapia. 2004;75(3-4):368-370. PMID: 15158997. Available from: https://doi.org/10.1016/j.fitote.2003.12.020.

9. Hassan MC, Healey MT, Waterman GP. Kolavane and Kaurane diterpenes from the stem bark of Xylopia aethiopica. Phytochemistry. 1982;21(6):1365 -1368. Available from: https: //doi.org/10.1016/0031-9422(82)80143-X.

10. Tegang AS, Beumo TMN, Dongmo PMJ, Ngoune LT. The essential oil of Xylopia aethiopica from Cameroun; chemical composition, antiradical and in vitro antifungal activity against some mycotoxigenic fungi. J King Saud Univ Sci. 2018;30:466 -471. Available from: https://doi.org/10.1016/j.jksus.2017.09. 011.

11. Ekeanyanwu RC, Etienajirhevwe OF. In vitro anthelminthic potentials of Xylopia aethiopica and Monodora myristica from Nigeria. AJBR. 2012;6:115-120. Available from: https://doi. org/10.5897/AJBR11.083.

12. Oliveira JD, Alves DKM, Miranda MLD, Alves JM, Xavier MN, Cazal CM, et al. Chemical composition of essential oil extracted from leaves of Campomanesia adamantium subjected to different hydrodistillation times. Ciênc Rural. 2017;47(1):1-7. Available from: https://doi.org/10.1590/01038478 cr20151131.

13. OECD. OECD 423 - Guidelines for the testing of chemicals. Acute oral toxicity -Fixed-dose procedure. Animals. 2001;p. 1-14. Available from: doi.org/10.1787/20745788.

14. OECD. OECD 407 - Guidelines for the testing of chemicals. Repeated dose 28-day oral toxicity study in rodents. Guidel Test Chem. 2008;p. 1-13. Available from: https://ntp.niehs.nih.gov/ iccram/suppdocs/feddocs/oecd/oecdtg407-2008.pdf.

15. Ekeanyanwu R, Njoku OU. Acute and Subacute oral toxicity study on the flavonoid-rich fraction of Monodora tenuifolia seed in albino rats. Asian Pac J Trop Med. 2014;4(3):194-202. Available from: https://doi.org/10.1016/S2221-1691(14)602318.

16. Mbaka GO, Adeyemi OO, Oremosu AA. Acute and subchronic toxicity studies of the ethanol extract of the leaves of Sphenocentrum jollyanum (menispermaceae). Agric Biol J N Am. 2010;1(3):265 -272. Available from: https://doi.org/10.5251/ abjna.2010.1.3.265.272.

17. Mbaka GO, Adeyemi OO. Toxicity study of ethanol root extract of Sphenocentrum jollyanum (menispermaceae) pierre. Asian J Exp Biol Sci. 2010;1(4):869-874.

18. Olonisakin AM, Oladimeji O, Lajide L. Composition and Antibacterial Activity of Steam Distilled Oils of Xylopia aethiopica and Syzigium aromaticum. J Eng Appl Sci. 2007;2:236240. Available from: http://medwelljournals.com/abstract/ ?doi=jeasci.2007.236.240.
19. Loziene K, Venskutonis PR. Influence of environmental and genetic factors on the stability of essential oil composition of Thymus pulegioides. Biochem, Syst, Ecol. 2004;33:517-525. Available from: https://doi.org/10.1016/j.bse.2004.10.004.

20. Rajeswara BR, Kaul PN, Mallavarapu GR, Ramesh S. Effect of seasonal climatic changes on biomass yield and terpenoid composition of rose-scented geranium. Biochemical Systematics and Ecology. 1996;24:627-635. Available from: https: //doi.org/10.1016/S0305-1978(96)00071-3.

21. Abd-Algader NN, El-kamali HH, Ramadan MM, Ghanem KZ, Farrag ARH. Xylopia aethiopica volatile compounds protect against Panadol-induced hepatic and renal toxicity in male rats. World Appl Sci J. 2013;27(1):10-22. Available from: 10.5829/idosi.wasj.2013.27.01.13603.

22. Imo C, Yakubu OE, Imo NG, Udegbunam IS, Onukwugha OJ. Chemical composition of Xylopia aethiopica fruits. A, J, Physiol, Biochem, Pharmacol. 2018;7(2):48-53. Available from: https://doi.org/10.5455/ajpbp.20180521064020.

23. El-Kamali $\mathrm{HH}$, Adam HO. Aromatic plants from Sudan: part II. Chemical composition of the essential oil of Xylopia aethiopica (Dunal) A. Rich-Existence of chemotype species. ANAS. 2009;3(2):166-169.

24. Niamayoua RK, Silou T, Bassiloua JB, Diabangouaya M, Loumouamou AN, Chalchat JC. Characterization of essential oils of Xylopia aethiopica (Dunal) A. Rich for forestation of the coastal Savana at Pointe-Noitre (Congo-Brazzaville). AJFST. 2013;6(6):728 -736. Available from: https://doi.org/10.19026/ ajfst.6.102.

25. Zárybnický T, Boušová I, Ambrož M, Skálová L. Hepatotoxicity of Monoterpenes and Sesquiterpenes. Arch Toxicol. 2017;92(1):1-13. PMID: 28905185. Available from: https: //doi.org/10.1007/s00204-017-2062-2.

26. National Research Council (NRC). Toxicity Testing for Assessing Environmental Agents; Interim Report. National Academics Press: Washington, DC, USA. 2006;Available from: https://doi.org/10.17226/11523.

27. Mirza A, Paschal SS. Safety Evaluation of Syringic acid: subacute oral toxicity studies in Wistar rats. Heliyon. 2019;5:e02129. PMID: 31463381. Available from: https://doi org/10.1016/j.heliyon.2019.e02129.

28. Hilaly J, Israili H, Lyoussi B. Acute and chronic toxicological studies of Ajuga iva in experimental animals. J Ethnopharmacol. 2004;91:43-50. PMID: 15036466. Available from: https: //doi.org/10.1016/j.jep.2003.11.009.

29. Porwal M, Khan NA, Maheshwari KK. Evaluation of acute and sub-acute oral toxicity induced by ethanol extract of Marsdenia tenacissima leaves in experimental rats. Sci Pharm. 2017;85(3):29. PMID: 28825665. Available from: https://doi. org/10.3390/scipharm85030029.

30. Odeyemi OO, Yakubu MT, Masika PJ, Afolayan AJ. Toxicological evaluation of the essential oil from Menthalongifolia L. subsp. capensis leaves in rats. J Med Food. 2009;12:669-674. PMID: 19627219. Available from: https://doi.org/10.1089/jmf. 2008.0136.

31. Olorunnisola OS, Bradley G, Afolayan AJ. Acute and subchronic toxicity studies of methanolic extract of Tulbaghia violacea rhizomes in Wistar rats. Afr J Biotechnol. 2012;11:1493414940.

32. Greaves P. Histopathology of preclinical toxicity studies; interpretation and relevance in drug safety evaluation. Academic Press. 2011;. 